\title{
The Effect of Transformational Ledership, Integrity and Teamwork on Lectures Work Effectiveness
}

\author{
Safrul $^{1}$, Thamrin Abdullah ${ }^{2}$, Ma'ruf Akbar ${ }^{3}$ \\ \{safrul_kodri@uhamka.ac.id ${ }^{1}$, Thamrin.Abdullah@yahoo.co.id ${ }^{2}$, makrufakbar@unj.ac.id $\left.{ }^{3}\right\}$ \\ Universitas Muhammadiyah Prof. DR. HAMKA, Indonesia ${ }^{1}$ \\ Universitas Negeri Jakarta, Indonesia ${ }^{23}$
}

\begin{abstract}
The purpose of this study was to investigate the effects of transformational leadership, integrity and teamwork on lecturers' work effectiveness at University of Muhammadiyah Prof. Dr. Hamka, Jakarta. The results of the research revealed that transformational leadership, integrity and teamwork have direct positive effects on the work effectiveness. It also proved that transformational leadership and Integrity have direct positive effects on the team work. The research sample were 193 lecturers taken proportionally. Data collection techniques using questionnaire instruments. The assesment of data was carried out through the path analysis techniques. From the results, Transformational leadership, integrity, and teamwork have a positive effect on lecturers' work effectiveness at University of Muhammadiyah Prof. Dr. Hamka Jakarta.
\end{abstract}

Keywords: Transformational leadership, integrity, teamworks, work effectiveness.

\section{Introduction}

In carrying educating and teaching, research and community service in universities, lecturers can work optimally in order to achieve work effectiveness. A lecturer must follow the compiled plans to produce effective results corresponding to the purpose of work. Hackman in Tohidi (2011) reported "Work effectiveness is defined in a three dimensional definition: the group's output meeting quality standards, the group's ability to work interdependently in the future, and the growth and well-being of team members." According to Guzzo (2011: 1143), "work effectiveness is defined as a combined, measure of team performance and viability,". [7] Mullin (2010) stated the meaning of effective as "doing the right things and relates to outputs of the job." [8] Mullin further illustrated that the meaning of effectiveness can be divided into two aspects. These include (1) Effectiveness related to doing the right things, that is, the implemented work based on standard and compiled procedures. The compatibility of planning and implemention generates the right works. (2) There is effectiveness related to the result of implemented works. The congeniality of the program and result affects the effectiveness of an organization managerial style and is appropriate to its goals. Drucker (2006) stated that "effectiveness is related to getting the right things done." Still, Drucker stipulates that effectiveness is great work generated by the organization or persons. Based on previous research and theoretical study, it is affected by transformational leadership, integrity and teamwork. The effectiveness of lecturers at University of Muhammadiyah Prof. Dr. HAMKA is not optimal. From the data in the academic system in 2016/2017, the data obtained were from 153 lecturers or $38 \%$ of 386 , which is not in 
accordance with the academic system 16 times face to face. In addition, 131 or $30 \%$ of teaching lecturers exceed the requirement of 12 credits per semester. [9]

Transformational leadership. Burns in Bass (2006) established that "transformational leadership is a an approach that causes change in individuals as well as social systems." [10] It influences someone to take change and uphold his integrity in work implementation according to the goals set. Furthermore, Burns portrayed transformation of leadership as a process in which leaders and followers help each other to advance to a higher level of morale and motivation, thereby accomplishing tasks according to the desires of both leaders and the followers Bass (2006). [11]

Integrity. Nillsen (2004) reported that "integrity is taken to mean honesty or sincerity, or some other such qualities in a person. Someone should be honest, sincere, and qualified to achieve appropriate results. A sincere and honest character is trusted by the leader and the group members in the organization [12] Huberts, Kaptein et al. (2007) perceived integrity as an important precondition for the smooth functioning of profitable organizations." The report is also supported by the assertion that "An organization with integrity strengthens stakeholder confidence" as reported by ShawnHuberts, Kaptein et al. (2007). [13]

Teamwork. An excerpted of Ingram opinion,Manzoor, Ullah et al. (2011) reported "teamwork is a strategy that has the potential to improve the performance of individuals and organizations, though it should be nurtured over time." It means the success of the organizations and individuals in optimal productivity should be developed by solid teamwork. [14] Parker (2008) stated that effective teamwork is critical for success[15]. Maximum productivity obtained by teamwork due to opinion and suggested interaction of members in an organization to completing tasks in accordance with compiled arrangement. Bruce and Ricketts stated "teamwork is extremely important among cross-disciplinary groups in order to produce effective and efficient work"[16]. Teamwork is a designed activity and accomplished by an organization and therefore cooperation of each element improves it.

\section{Methodology}

The study used quantitative reserach with survey method. The total population was 386, all lectures at University Muhammadiyah Prof. Dr. Hamka Jakarta. Sample of 193 lecturers as respondents was set in proportional sampling by means of Slovin formula. The research instrument was questionnaire using Likert scale filled by respondents. The results of the survey were analyzed using multivariate statistics with path analysis.( see at https://osf.io/9kmpn/ )

\section{Result}

The results of normality test analysis show that the data is normally distributed in estimated errors testing in the regression equation $\mathrm{Y}$ on $\mathrm{X}_{1}\{\hat{\mathrm{Y}}=70.89+0.37 \mathrm{X} 1\}$. The result of F-count $=41.96$ was greater than the value of F-table 6.77 at $\alpha=0.01$. Because the value of F-count $>$ F-table, the regression was stated to be very significant. On the other hand, the results of linearity testing obtained F-count of 0.74 smaller than F-table of 1.49 at $\alpha=0.05$. Because F-count $<$ F-table, the regression of $\mathrm{Y}$ on $\mathrm{X} 1$ was linear. The test of significance and linearity of the regression equation $\mathrm{Y}$ on $\mathrm{X}_{2}\{\hat{\mathrm{Y}}=81.54+0.33 \mathrm{X} 2\}$ obtained F-count $=38.77$, 
greater than the value of F-table 6.77 at $\alpha=0.01$. Because the results of F-count> F-table, the regression was stated to be very significant. Assessment of the linearity test showed the results of F-count of 0.91 was smaller than that of F-table of 1.47 at $\alpha=0.05$. Since the result of Fcount $<\mathrm{F}$-table, the regression of $\mathrm{Y}$ to $\mathrm{X}_{2}$ was linear. Besides, the test of significance and linearity in the regression equation $\mathrm{Y}$ on $\mathrm{X}_{3}\{\hat{\mathrm{Y}}=56.12+0.49 \mathrm{X} 3\}$, obtained F-count $=42.01$ greater than the value of F-table 6.77 at $\alpha=0.01$. Because the results of F-count> F-table, the regression was stated to be very significant. Similarly, the linearity test gave the results of Fcount of 1.29 smaller than F-table of 1.54 at $\alpha=0.05$. Since the result of F-count $<$ F-table, the regression of $\mathrm{Y}$ over $\mathrm{X} 3$ was linear. Testing the significance and linearity of the regression equation $\mathrm{X}_{3}$ to $\mathrm{X}_{1}\left\{\dot{\mathrm{X}}_{3}=104.25+0.23 \mathrm{X} 1\right\}$, the results of $\mathrm{F}$-count $=19.08$, greater than the value of F-table 6.86 at $\alpha=0.01$. Because the results of F-count> F-table, the regression was stated to be very significant. In the linearity test, the results of F-count of 1.10 were smaller than F-table of 1.49 at $\alpha=0.05$. Since the result of F-count $<F$-table, the regression $X_{3}$ to $X_{1}$ was linear. The results of testing significance and linearity in the regression equation $\mathrm{X}_{3}$ to $\mathrm{X}_{2}$ $\left\{\mathrm{X}_{3}=111.13+0.20 \mathrm{X}_{2}\right\}$. showed F-count $=17.28$, greater than the value of F-table 6.77 at $\alpha=$ 0.01 . Because the results of F-count $>$ F-table, the regression was stated to be very significant. The linearity test obtained the results of Fcount of 0.91 smaller than F-table of 1.47 at $\alpha=$ 0.05. Since the result of F-count $<F$-table, the regression $X_{3}$ to $X_{2}$ was linear. The results of the calculation of the significance test and linearity in the regression equation $X_{2}$ to $X_{1}\{X 2=$ $\left.89.97+0.24 \mathrm{X}_{1}\right\}$ showed $\mathrm{f} F$-count $=10.07$, greater than the value of F-table 6.77 at $\alpha=0.01$. Because the results of F-count $>$ F-table, the regression was very significant. The results of linearity testing obtained the results of F-count of 0.71 , a value smaller than F-table of 1.49 at $\alpha=0.05$. With the results of F-count $<$ F-table the regression $X_{2}$ to $X_{1}$ was linear. The summary of results analysis was as shown in table 1 bellow.

Table 1.Data on the Results of Significance Regression and Linearity

\begin{tabular}{|c|c|c|c|c|c|c|c|}
\hline \multirow[t]{3}{*}{ Regression } & \multirow[t]{3}{*}{ Regression Equation } & \multicolumn{3}{|c|}{ Siginificance Test } & \multicolumn{3}{|c|}{ Linearity Test } \\
\hline & & \multicolumn{3}{|c|}{ F-table } & & \multicolumn{2}{|c|}{ F-table } \\
\hline & & F-count & 0,05 & 0,01 & F-count & 0,05 & 0,01 \\
\hline $\mathrm{Y}$ on $\mathrm{X}_{1}$ & $\hat{\mathrm{Y}}=70,89+0,37 \mathrm{X}_{1}$ & 41,69 & 3,89 & 6,77 & 0,74 & 1,49 & 1,75 \\
\hline $\mathrm{Y}$ on $\mathrm{X}_{2}$ & $\hat{\mathrm{Y}}=81,54+0,33 \mathrm{X}_{2}$ & 38,77 & 3,89 & 6,77 & 0,91 & 1,47 & 1,72 \\
\hline $\mathrm{Y}$ on $\mathrm{X}_{3}$ & $\hat{Y}=56,12+0,49 X_{3}$ & 42,01 & 3,89 & 6,77 & 1,29 & 1,54 & 1,83 \\
\hline $\mathrm{X}_{3}$ to $\mathrm{X}_{1}$ & $\dot{\mathrm{X}}_{3}=104,25+0,23 \mathrm{X}_{1}$ & 19,08 & 3,89 & 6,77 & 1,10 & 1,49 & 1,75 \\
\hline$X_{3}$ to $X_{2}$ & $\dot{\mathrm{X}}_{3}=111,13+0,20 \mathrm{X}_{2}$ & 17,28 & 3,89 & 6,77 & 0,91 & 1,47 & 1,72 \\
\hline $\mathrm{X}_{2}$ to $\mathrm{X}_{1}$ & $\dot{X}_{2}=89,97+0,24 X_{1}$ & 10,07 & 3,89 & 6,77 & 0,71 & 1,49 & 1,75 \\
\hline
\end{tabular}

Table 2.Path Coefficient

\begin{tabular}{lccc}
\hline \multicolumn{2}{c}{ Path } & Path Coefficient & t-count \\
\hline $\mathrm{X}_{1}, \mathrm{Y}$ & $\rho_{\mathrm{y} 1}$ & 0,284 & 4,56 \\
$\mathrm{X}_{2}, \mathrm{Y}$ & $\rho_{\mathrm{y} 1}$ & 0,272 & 4,38 \\
$\mathrm{X}_{3}, \mathrm{Y}$ & $\rho_{\mathrm{y} 1}$ & 0,261 & 4,11 \\
$\mathrm{X}_{3}, \mathrm{X}_{1}$ & $\rho_{31}$ & 0,249 & 3,61 \\
$\mathrm{X}_{3}, \mathrm{X}_{2}$ & $\rho_{32}$ & 0,232 & 3,37 \\
\hline
\end{tabular}




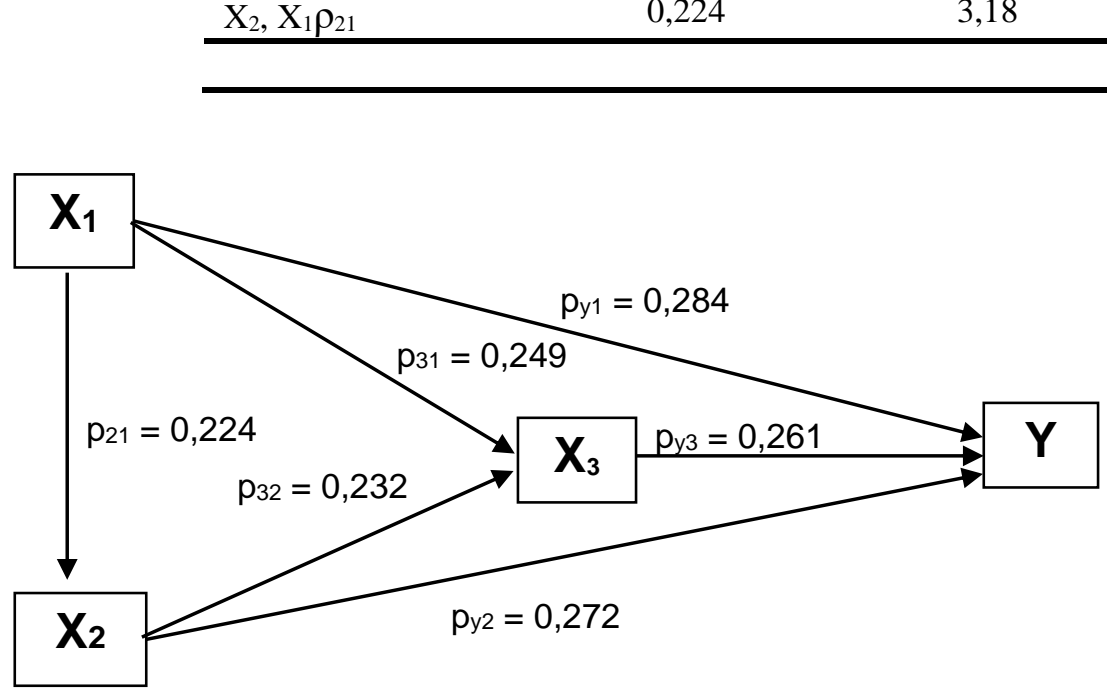

Fig. 1. Path coefficient model

\section{Discussion}

The results path coefficient calculation of the transformational leadership on work effectiveness $\left(\mathrm{X}_{1}\right.$ on $\left.\mathrm{Y}\right)$ were 0.284 with a $\mathrm{t}$-count of 4.56 . since the $\mathrm{t}$-count was greater than the t-table value at degree of freedom $=189$ for $\alpha=0.01$ at 2.60 , the null hypothesis $\left(\mathrm{H}_{0}\right)$ is rejected and hypothesis one $\left(\mathrm{H}_{1}\right)$ accepted. It means there was a very significant positive direct influence between transformational leadership on work effectiveness. This is consistent with Colquitt, LePine et al. (2016) opinion that "Transformational leadership has a moderate positive relationship with job performance and a strong positive correlation with organizational commitment." [17] The research of Bono \& Judge in Ali, Jangga et al. (2015) found that "a transformational leader influences the followers to achieve goals as well as to increase confidence, commitment and job performance." [18]. In line with the opinions of Kevin Kelloway, Barling et al. (2003), Leaders manifest idealized influence when they make improvements in the organization's performance by participating in risky initiatives with their followers, maintain consistency in their behavior, and being dependable." [19] Work effectiveness is directly affected by transformational leadership. The second hypothesis was integrity and work effectiveness $\left(\mathrm{X}_{2}\right.$ on $\left.\mathrm{Y}\right)$ is 0.272 with a t-count of 4.38 . Because it was greater than the t-table value at degree of freedom $=189$ for $\alpha=0.01$ at 2.60 then null hypothesis $\left(\mathrm{H}_{0}\right)$ is rejected and hypothesis one $\left(\mathrm{H}_{1}\right)$ accepted. That means there is a very significant positive direct influence between integrity and work effectiveness. The finding of this study related to Parry and Proctor-Thomson (2002) opinion that "in support of previous findings, perceived integrity was also found to correlate positively with leader and organisational effectiveness measures. Integrity should influence work effectivenes to support organizational achievements." [20]. The third hypothesis $\left(\mathrm{H}_{3}\right)$ was of the teamwork on work effectiveness $\left(\mathrm{X}_{3}\right.$ on $\left.\mathrm{Y}\right), 0.261$ with a t-count of 4.11. Since it was greater than the value of $\mathrm{t}$ table at degree of freedom $=189$ for $\alpha=0.01$ at 2.60 , the null $\left(\mathrm{H}_{0}\right)$ was rejected and hypothesis one $\left(\mathrm{H}_{1}\right)$ accepted. This implired that there is a very significant positive direct 
influence between the teamwork and work effectiveness. The findings of this hypothesis is similar to the results of Schermerhorn and Wright (2007)research which established that where teamwork is positive in a highly cohesive work group, the resulting conformity to the norm has a positive effect on work effectiveness." Positive teamwork in a work group, in accordance with existing norms, has a positive effect on work effectiveness. [21] . The fourth hypotesis of the transformational leadership on teamwork $\left(X_{3}\right.$ to $\left.X_{1}\right)$ was 0.249 with a t-count of 3.61. Because the value of the t-count coefficient was greater than the value of $t$-table at degree of freedom $=190$ for $\alpha=0.01$ at 2.60, the null hypothesis $\left(\mathrm{H}_{0}\right)$ was rejected and hypothesis $\left(\mathrm{H}_{1}\right)$ accepted. This means there is a very significant positive direct effect of transformational leadership on teamwork. This leads to a conclusion that teamwork is positively influenced by transformational leadership. This finding is relevant to Bass (2006) finding that "transformational leadership had a positive impact on the work group potency, which, in turn, had positive effects on team performance." [10] The fifth hypothesis found the result of the integrity on teamwork $\left(\mathrm{X}_{3}\right.$ to $\left.\mathrm{X}_{2}\right)$ is 0.232 with a tcount of 3.37 . Therefore the value of $t$-count was greater than the value of t-table at degree of freedom $=190$ for $\alpha=0.01$ at 2.60. The null hypothesis $\left(\mathrm{H}_{0}\right)$ was rejected and hypothesis $\left(\mathrm{H}_{1}\right)$ accepted, meaning there was a very significant positive direct influence between the integrity and teamwork. This is relevant to the Thomson and Simon study in Hooijberg, Lane et al. (2010) which established that "There is a significant positive correlation between the concepts of perceived integrity and work effectivenes."

The results of the transformational leadership on integrity $\left(X_{1}\right.$ to $\left.X_{2}\right)$ were 0.224 with a tcount of 3.18. with the tcount being greater than the $\mathrm{t}$ table at $\mathrm{dk}=191$ for $\alpha=0.01$ at 2.60, the null hypothesis $\left(\mathrm{H}_{0}\right)$ was rejected and the alternative hypothesis $\left(\mathrm{H}_{1}\right)$ accepted. The implication of this was that there is a very significant positive direct effect of transformational leadership on the integrity. Therefore, it is correct conclude that integrity is influenced by transformational leadership directly. This means increased transformational leadership of the heads of departments improved the integrity of lecturers. This is relevant to the Tuknett study in Duggar (2011) which found thatthe influence of integrity is the foundation of transformational leadership and involves a careful balance between respect and responsibility. It influences the integrity, respect and responsibilty in the organizational environment. [22]

\section{Conclusion}

From the six hypotheses test are all vital and of significance in this regard. The firstonetransformasional leadership gives largest siginificance, that is $\rho_{\mathrm{y} 1}=0,824$.Next. The second hypotheses, integrity on work effectiveness, gives smallest significance, $\rho_{\mathrm{y} 1}=0,272$. The third one, the teamwork on work effectiveness has smallest siginificance of $\mathrm{p}_{\mathrm{y} 3}=0,261$. The fourth hypothesis, teamwork to transformtional leadership has a significance $\mathrm{p}_{31}=0,249$. The fifth one, teamwork to integrity gives significance $\mathrm{p}_{32}=0,232$, and the last one, integrity to transformational leadership had significance $\mathrm{p}_{31}=0,224$. That means transformationalleadership, integrity and teamwork have significance to work effectiveness on lectures at University Muhammadiyah Prof. Dr. Hamka.

\section{References}

[1] Tengpongsthorn, W.: Factors affecting the effectiveness of police performance in Metropolitan Police Bureau. Kasetsart Journal of Social Sciences 38(1): 39-44. (2017) 
[2] Arokiasamy, A. R. A.: Transformational leadership of school principals and organizational health of primary school teachers in Malaysia Elsevier. (2016)

[3] Samad, S. : The Influence of Innovation and Transformational Leadership on Organizational Performance. Procedia - Social and Behavioral Sciences 57: 486-493. (2012)

[4] Sadeghi, A. and Z. A. L. Pihie : Transformational Leadership and Its Predictive Effects on Leadership Effectiveness. International Journal of Business and Social Science 3(7): 186-197. (2012)

[5] Nillsen, R. (2004).:The concept of integrity in teaching and learning. Newcastle, University of Newcastle.

[6] Cohen, S. G.: Designing Effective Self-Managing Work Teams. California, Center for effective organizations, University of Southern California. (1993)

[7] Tohidi, H.).: Teamwork productivity \& effectiveness in an organization base on rewards, leadership, training, goals, wage, size, motivation, measurement and information technology. Procedia Computer Science 3: 1137-1146. (2011)

[8] Mullin, L. J. : Management and organization Behavior. London, Pearson Education. (2010)

[9] Drucker, P. F.: The effective executive: the definitive guide to getting the right things done. New York, Collins. (2006)

[10] Bass, B. M.: Transformational Leadership. Mahwah, New Jersey, Lawrence Erlbaum Associated Publisher. (2006)

[11] Hall, J., J. Shannon, et al. : Transformational Leadership: The Transforma-tion of Managers and Associates. Florida, US, Ifas Extension. (2015)

[12] Hooijberg, R., N. Lane, et al. : Leader effectiveness and integrity: wishful thinking? International Journal of Organizational Analysis 18(1): 59-75. (2010)

[13] Huberts, L. W. J. C., M. Kaptein, et al.: A study of the impact of three leadership styles on integrity violations committed by police officers. Policing: An International Journal 30(4): 587-607. (2007)

[14] Manzoor, S. R., H. Ullah, et al.: Effect of Teamwork on Employee Performance. International Journal of Learning \& Development 1(1): 110-126. (2011)

[15] Parker, G. M.: Team Players and Teamwork: New strategies for developing succesfull collaboration. San Fransisco, Jossey - Bass. (2008)

[16] Adams, B. L., H. R. Cain, et al.: Leadership, Motivation, and Teamwork Behaviors of Principal Investigator's in Interdisciplinary Teams: A Synthesis of Research. Journal of Leadership Education 11(2): 176-191. (2012)

[17] Colquitt, J., J. A. LePine, et al.: Organizational Behavior: Improving Performance and Commitment in the Workplace, McGraw-Hill Education. (2016)

[18] Ali, N. M., R. Jangga, et al.: Influence of Leadership Styles in Creating Quality Work Culture. Procedia Economics and Finance 31: 161-169. (2015)

[19] Kevin Kelloway, E., J. Barling, et al.: Remote transformational leadership. Leadership \& Organization Development Journal 24(3): 163-171. (2003)

[20] Parry, K. W. and S. B. Proctor-Thomson.: Perceived Integrity of Transformational Leaders in Organisational Settings. Journal of Business Ethics 35(2): 75-96. (2002)

[21] Schermerhorn, J. R. and B. Wright.: Management Fundamentals, John Wiley \& Sons Canada, Limited. (2007)

[22] Duggar, J. W.: The role of integrity in individual and effective corporate leadership. Journal of Academic and Business Ethics 3: 1-7. (2011) 